\title{
KEADILAN ELEKTORAL BAGI PEMILIH PENYANDANG DISABILITAS MENTAL PADA PEMILU SERENTAK 2019 DI SURABAYA
}

\author{
Nikita Desverose ${ }^{1}$, Priyatmoko ${ }^{2}$ \\ ${ }^{1}$ Departemen Politik, Fakultas Ilmu Sosial dan Ilmu Politik, Universitas Airlangga \\ desverose59@gmail.com \\ ${ }^{2}$ Departemen Politik, Fakultas Ilmu Sosial dan Ilmu Politik, Universitas Airlangga \\ priyatmoko@fisip.unair.ac.id
}

\begin{abstract}
This research focuses on upholding political justice in elections for mentally disabled people, more precisely about how the state and its institutions seek to restore political rights and implement inclusive election policies for person with mental disabilities regarding their participation in elections and their right to vote when election. This research takes two main topics, namely restoration of political rights of mentally disabled people in elections through the regulation of the Election Law, and the making of special rules to accommodate the needs of mental disabled people in elections and the implementation of these policies in the 2019 elections in the city of Surabaya. Data obtained through the analysis of news content and interviews with sources that are then processed and explained qualitatively descriptive. The theory used in this research is electoral justice theory, with a focus on conformity in the field with elements of justice in the electoral justice system. The results obtained are in the first part, the regulation carried out by the government based on complaints from community organizations that focus on defending mental disability rights and electoral issues, meets the criteria for fulfilling rights and distributing justice first where the state gives equal rights for everyone to channel their voice in elections, without discriminating any group by giving them access to the right to be registered as DPT and entitled to participate in the election process. In the second part, it discussed the implementation of the policy in the city of Surabaya, specifically at the Menur Hospital and found that the state tried to accommodate the political rights of the mentally disabled in elections by providing more specific technical rules by adjusting the conditions and needs of the mentally disabled, which according to the elements election justice which requires electoral governance to protect citizens' voting rights. The final conclusion of this study illustrates how the state and its institutions fulfill the elements of the electoral justice system in distributing justice in elections, for people with mental disabilities in Indonesia, especially in the city of Surabaya in the 2019 Elections.
\end{abstract}

Keywords: Electoral Justice, 2019 Elections, Person with Mental Disabilities.

\section{PENDAHULUAN}

Keadilan politik merupakan hal yang sangat penting dalam menjamin terpenuhinya hak-hak sipil dan politik warga suatu negara, di mana hak sipil dan politik merupakan hak dasar dari hak-hak asasi manusia yang ada, dan harus dipenuhi sebelum seseorang dapat mengakses hak-hak sosial dan ekonominya. Ketika hak sipil dan hak politik seseorang dipenuhi, dia dapat dikatakan sebagai manusia yang merdeka dan berhak mendapat akses terhadap fasilitas-fasilitas dalam negara yang dapat membantunya mencapai kesejahteraannya. Negara-negara di dunia ini dapat dikatakan memiliki tanggung jawab dalam mendistribusikan keadilan itu bagi rakyatnya. Keadilan tersebut salah satunya harus diberikan dalam bentuk hak suara seseorang dalam pemilihan umum, yang merupakan salah satu instrumen demokrasi yang terlembaga untuk melakukan transfer kekuasaan dari tangan rakyat kepada calon pemerintah.

Keadilan juga menjadi salah satu asas dan prinsip Pemilu yang penting, sehingga semaksimal mungkin penyelenggara Pemilu harus menyelenggarakan Pemilu yang sesuai dengan asas tersebut. 
Selama ini telah banyak upaya dilakukan negara dan banyak lembaga di dalamnya, baik yang bersifat formal maupun informal, untuk menjamin pemilihan umum yang adil bagi semua pihak. Upaya-upaya untuk mewujudkan Pemilu yang inklusif pun telah banyak dilakukan, khususnya untuk menjamin hak partisipasi politik para penyandang disabilitas. Sayangnya, masih ada bagian dari kelompok tersebut yang belum sepenuhnya tersentuh dan mendapatkan keadilan untuk ikut serta dalam pemilihan umum, yaitu mereka yang menyandang disabilitas mental.

Permasalahan-permasalahan yang muncul mengenai hak penyandang disabilitas mental untuk berpartisipasi dalam Pemilu, antara lain seperti tidak dilakukannya pendataan secara menyeluruh pada difabel mental baik yang dirawat inap di rumah sakit jiwa atau rawat jalan di luar rumah sakit ketika masa pendataan dan pemutakhiran daftar pemilih oleh Petugas Pemutakhiran Data Pemilih (PPDP), adanya pencoretan nama-nama penyandang disabilitas mental dari Daftar Pemilih Tetap (DPT) seperti pada periode Pemilu 2014 di beberapa daerah di Indonesia (kbr.id), belum tersedianya TPS yang memenuhi syarat-syarat kelayakan akses bagi penyandang disabilitas di banyak tempat ketika Pemilu dilaksanakan, hingga disahkannya aturan yang mensyaratkan seseorang tidak boleh terganggu jiwa atau ingatannya ketika akan didaftar menjadi pemilih dalam Undang-Undang Pilkada No. 8 Tahun 2015 ayat (3) huruf (a) yang secara langsung mencabut hak konstitusional pemilih penyandang disabilitas mental (dpr.go.id).

Kebanyakan permasalahan tersebut muncul karena kesalahan stigma di masyarakat tentang penyandang disabilitas mental. Mereka dianggap tidak bisa berpikir dan berperilaku secara benar setiap waktu, padahal sejatinya disabilitas yang mereka derita bersifat episodik dan banyak dari kelompok difabel mental yang masih dapat menjalankan fungsinya sebagai warga negara dan bagian masyarakat selayaknya orang non-difabel mental dalam kehidupan sehari-hari. Selain itu, pentingnya partisipasi setiap warga negara, terlepas dari dia penyandang disabilitas mental atau bukan, pada proses input dalam sistem politik, yaitu Pemilu masih kurang dipahami oleh banyak pihak, bahkan oleh penyelenggara Pemilu itu sendiri.

Ketika permasalahan yang ada sudah sampai mengebiri hak konstitusional dan mencederai hak asasi penyandang disabilitas mental sebagai seorang warga negara, ini tidak bisa dibiarkan begitu saja. Aturan tersebut kemudian diajukan untuk diuji secara yudisial (judicial review) karena dianggap cacat hukum dan kontradiktif dengan Deklarasi Universal Hak Asasi Manusia yang telah diratifikasi Indonesia, dan Undang-Undang, serta aturan-aturan lainnya yang justru sejak awal menjamin hak-hak penyandang disabilitas, termasuk penyandang disabilitas mental.

Penelitian ini menjadi penting untuk diteliti karena relevan dengan diskursus keadilan Pemilu yang sedang terjadi di masyarakat. Kurangnya edukasi dari pemerintah sejak dini mengenai hak-hak sipil dan politik setiap warga yang harus dipenuhi, membuat kelompok penyandang disabilitas mental ini menjadi dirugikan, dalam aspek penyaluran hak suaranya dalam Pemilu. Secara tidak langsung eksklusivitas tersebut telah mencabut hak dasar mereka sebagai warga negara dan tentu hal tersebut tidak dapat dibiarkan terus-menerus. 
Pada kajian-kajian sebelum ini mengenai Pemilu inklusif bagi kelompok penyandang disabilitas di Indonesia, belum ada yang spesifik mengangkat difabel mental sebagai subyek dalam penelitiannya, hanya membahas penyandang disabilitas secara general dalam Pemilu. Posisi penelitian ini dalam bidang kajian keadilan politik adalah sebagai pelengkap dari kajian-kajian yang telah ada sebelumnya. Penelitian ini berusaha menghadirkan penyandang disabilitas mental sebagai subyek spesifik yang harus dipulihkan dan dibela hak-haknya dalam bernegara. Kontribusi yang berusaha diberikan melalui penelitian ini adalah sebagai bahan kajian dan literatur tambahan mengenai distribusi keadilan politik bagi pemilih penyandang disabilitas mental, khususnya dalam proses Pemilu.

\section{METODOLOGI PENELITIAN}

Data dalam penelitian ini diperoleh melalui analisa isi berita dan wawancara dengan narasumber yang berkaitan dengan upaya restorasi hak pilih penyandang disabilitas mental dan implementasinya pada Pemilu serentak 2019 di Surabaya. Metode yang digunakan adalah kualitatif deskriptif yang berusaha menggambarkan keadaan sesungguhnya yang terjadi dan bagaimana interpretasinya dilihat dari teori keadilan elektoral. Pada penelitian ini, pertama dibahas mengenai upaya restorasi hak pilih penyandang disabilitas mental oleh negara dan lembaga-lembaga di dalamnya melalui reregulasi Undang-Undang Pilkada yang dilihat dari aspek filosofis, sosiologis, dan yuridis. Kedua, akan dibahas mengenai implementasi Pemilu inklusif bagi penyandang disabilitas mental di Kota Surabaya pada periode Pemilu 2019.

\section{HASIL DAN PEMBAHASAN}

\section{Penegakan Pemilu Inklusif bagi Penyandang Disabilitas Mental di Surabaya Periode 2019}

Secara filosofis, perbaikan atas UU Pilkada Nomor 8 Tahun 2015 didasarkan pada pertimbangan terhadap hak-hak dasar manusia, termasuk bagi penyandang disabilitas mental, yang harus dipenuhi. Sebagai warga negara Indonesia, penyandang disabilitas mental memiliki hak yang sama dengan warga negara lainnya untuk mendapatkan pengakuan yang sama di mata hukum, termasuk hak politik dalam Pemilu, yaitu memilih dan dipilih.

Secara sosiologis, peran negara dan lembaga-lembaga di dalamnya dalam menciptakan keadilan politik bagi pemilih penyandang disabilitas mental pada Pemilu serentak 2019 dilakukan pertama-tama dengan reframing stigma terhadap disabilitas mental. Upaya mengubah sudut pandang ini menyangkut empat hal yang selalu distigmakan kepada penyandang disabilitas mental, yaitu penyamaan penyandang disabilitas mental dengan orang gila, kekhawatiran terhadap aksi vandalism yang akan dilakukan penyandang disabilitas mental atau orang dengan gangguan jiwa (ODGJ) saat melakukan pemilihan, kekhawatiran terhadap suara penyandang disabilitas mental dalam Pemilu dapat dimonopoli dan dimanipulasi, serta keraguan atas kapabilitas penyandang disabilitas mental dalam memilih.

Pertama, diperlukan perbaikan stigma mengenai perbedaan antara orang gila dengan difabel mental. Sebagian besar masyarakat selalu menganggap disabilitas mental itu sama dengan gila, dan hal 
tersebut sama sekali tidak tepat. Karena dari segi yuridis, tidak ada dalam undang-undang atau aturan lainnya yang menyebutkan dengan diksi "orang gila" yang cenderung lebih berkonotasi negatif. Sehingga, tidak ada undang-undang di Indonesia ini yang melarang penyandang disabilitas mental untuk ikut dalam Pemilu.

Perbedaan mendasar dari difabel mental dengan orang gila (yang terlunta-lunta di jalanan) adalah ada atau tidaknya dukungan yang didapat dalam memperbaiki kualitas hidup mereka sejak dan semasa mengidap disabilitas mental. Orang gila sudah pasti menyandang disabilitas mental, tapi penyandang disabilitas mental belum tentu orang gila. Spektrum disabilitas mental pun terbagai ke dalam berbagai kategori, dari yang ringan, akut, hingga kronik dan semuanya, selama bukan gangguan kejiwaan yang permanen, bersifat episodik. Mereka masih tetap memiliki kemampuan berpikir dan berperilaku yang baik ketika bukan dalam episode gangguan, contohnya bipolar dan depresi yang memiliki fluktuasi tertentu dan tidak terjadi setiap waktu untuk selamanya. Diluar masa episodiknya (atau disebut juga sebagai masa kambuh/relapse), penyandang disabilitas bisa bepikir dan berperilaku sebagaimana warga negara yang lain.

Kalau pun pada saat hari H Pemilu penyandang disabilitas mental mengalami relapse, maka mereka otomatis juga tidak akan ikut menyoblos karena dari tubuh dan pikirannya sendiri dia bahkan tidak mampu memenuhi kebutuhan dasar personalnya. Sama halnya seperti orang normal yang terdaftar di Daftar Pemilih Tetap (DPT), jika pada saat hari H orang tersebut sakit, tentunya ia juga tidak akan ikut menyoblos dan lebih memilih untuk berobat atau beristirahat total di rumah.

Kedua, mengenai kekhawatiran vandalisme oleh orang dengan gangguan jiwa (ODGJ) saat memilih. hal tersebut adalah stigma dan masalah yang perlu diluruskan. Disabilitas mental sifatnya episodik, ada episode relapse yaitu saat disabilitasnya kambuh dan ada masa sembuh dimana ia berfungsi selayaknya orang normal. Sehingga, jika berbicara mengenai potensi vandalisme, bukan hanya ODGJ yang berpotensi melakukan hal tersebut karena setiap orang memiliki potensi melakukan tindakan vandal dalam Pemilu, dan hendaknya anggapan atau keraguan macam ini dihentikan karena hanya akan merundung para penyandang disabilitas mental yang ingin menggunakan suaranya dalam Pemilu secara sadar dan rasional. Sekali lagi, karena sifatnya yang episodik, maka kemungkinan besar dan secara logis pemilih penyandang disabilitas mental hanya akan datang ke TPS untuk memilih ketika ia dalam kondisi sadar dan tubuh serta pikirannya mampu. Jika terjadi kekambuhan ketika di TPS atau kambuhnya berupa keinginan untuk melakukan kekacauan, maka hal tersebut dapat diatasi nantinya dengan pengamanan di TPS dan dukungan pendampingan dari pihak keluarga atau dokter jiwa yang bertanggung jawab atas difabel mental untuk mencegahnya pergi ke TPS.

Ketiga, kekhawatiran terhadap suara penyandang disabilitas mental dalam Pemilu dapat dimonopoli dan dimanipulasi juga ditemui oleh peneliti. Alasannya, masyarakat menilai penyandang disabilitas mental tidak mampu menentukan pilihannya sendiri secara rasional. Selain itu, sistem pendataan, indikator, dan jumlah penyandang disabilitas mental yang dianggap belum jelas, menguatkan anggapan bahwa suara penyandang disabilitas mental sangat mungkin dimonopoli dan dimanipulasi. 
Namun, anggapan tersebut kemudian diluruskan oleh beberapa informan dari berbagai latar belakang yang didapatkan oleh peneliti sebagai upaya menciptakan keadilan politik bagi pemilih penyandang disabilitas mental pada Pemilu serentak 2019 di Kota Surabaya. Secara umum tanggapan tentang kekhawatiran terjadinya manipulasi dan monopoli terhadap suara penyandang disabilitas mental dinilai sebagai pandangan yang tidak obyektif dan kurangnya pengetahuan masyarakat tentang disabilitas mental.

Kekhawatiran yang berlandaskan pandangan tidak obyektif ini tentu mendiskriminasi penyandang disabilitas mental, sebab kekurangan yang dimiliki penyandang disabilitas mental dijadikan kambing hitam jika terjadi manipulasi. Selain itu, pandangan tersebut juga tidak adil dikarenakan menganggap penyandang disabilitas mental mudah diarahkan sehingga dapat dimonopoli oleh pihakpihak yang tidak bertanggungjawab. Padahal peristiwa memonopoli suara juga terjadi di beberapa tempat seperti pondok pesantren yang telah menjadi rahasia umum. Fenomena monopoli suara pada Pemilu bukanlah alasan untuk mencabut hak pilih pemilihnya, termasuk penyandang disabilitas mental. Melainkan upaya dan kesempatan dalam memonopoli suara yang harus ditutup dan diberi aturan yang ketat.

Keempat, keraguan masyarakat mengenai kapabilitas penyandang disabilitas mental dalam memilih juga harus diluruskan kembali. Pasalnya, penyandang disabilitas mental bukanlah orang yang tidak memiliki kemampuan berpikir sama sekali, melainkan terdapat suatu waktu yang mereka dapat berpikir dan berperilaku sebagaimana manusia normal, dan terdapat pula waktu mereka tidak bisa berlaku seperti manusia normal dikarenakan spektrum yang beragam dan sifat gangguan yang episodik. Masyarakat harus diberikan edukasi mengenai hal ini, agar tidak lagi memandang episode relapse penyandang disabilitas mental sebagai representasi dari keseluruhan diri dan tindakannya, karena itu hanya sebagian hal yang melekat padanya dan bersifat parsial. Penyandang disabilitas mental masih mempunyai kemampuan untuk berpikir yang baik, kognitif yang baik, bisa membedakan hal yang benar dan yang salah, dan bisa bertanggung jawab atas keputusannya, maka mereka masih bisa memiliki hak untuk memilih.

Upaya-upaya sosiologis di atas menjadi dasar pengaduan tuntutan pembatalan aturan yang mendiskriminasi dan mengebiri hak pilih penyandang disabilitas kepada Mahkamah Konstitusi. Secara yuridis, pemulihan hak pilih bagi penyandang disabilitas mental bukanlah serta-merta pemberian dari Komisi Pemilihan Umum (KPU), melainkan undang-undang dan kerangka hukum Pemilu yang memungkinkan penyandang disabilitas mental untuk didata sebagai pemilih dan menggunakan hak pilihnya. Dalam Undang-Undang 7 Tahun 2017 tentang Pemilu dijelasakan bahwa yang mempunyai hak pilih adalah warga negara Indonesia yang sudah berusia 17 tahun pada hari $\mathrm{H}$ atau di bawah itu tetapi sudah atau pernah menikah. Artinya, siapapun yang sudah memasuki atau memenuhi syarat maka berhak menjadi pemilih, tidak melihat apakah seorang disabilitas mental atau tidak.

Pada lingkup yuridis internasional, Indonesia telah meratifikasi Konvensi PBB yaitu convention on the rights of persons with disabilities, yang kemudian disahkan dengan Undang-Undang Nomor 19 
Tahun 2011. Selain itu, diperkuat dengan pertimbangan atas aturan yang telah ada yaitu Undang-Undang Nomor 8 Tahun 2016 yang melindungi hak disabilitas, termasuk disabilitas mental, khususnya pada Pasal 13 tentang hak politik yang diantaranya memuat hak memilih dan dipilih dalam jabatan publik, peran aktif dalam Pemilu, pendidikan politik, hingga aksesibilitas pada sarana dan prasarana penyelenggaraan setiap pemilihan umum. Hasil judicial review itu adalah dikeluarkannya putusan MK Nomor 135/PUU-XIII/2015 yang membatalkan sebagian Pasal 57 Ayat 3 Huruf (a) UU Pilkada nomor 8 Tahun 2015, yaitu meniadakan persyaratan bahwa pemilih "harus tidak terganggu jiwa/ingatannya saat didata", sehingga penyandang disabilitas mental tetap mendapatkan hak pilihnya dan didata dalam DPT Pemilu.

Berkaitan dengan usulan prasyarat medis berupa surat rekomendasi dokter jiwa pada masa pendataan DPT, secara aturan hukum tidak ada undang-undang manapun yang mengatakan penyandang disabilitas harus diberi syarat khusus untuk mengikuti Pemilu. Hal ini dikarenakan hukum berpartisipasi dalam Pemilu di Indonesia adalah hak bukan kewajiban. Sehingga, digunakan atau tidak hak pilihnya menjadi kewenangan penuh rakyat, yang terpenting hak pilihnya tetap dilindungi yaitu dengan dimasukkan ke dalam daftar pemilih. Selain itu jika prasyarat tersebut diberlakukan, justru akan terjadi ketidakadilan karena lagi-lagi gangguan kejiwaan bersifat episodik, misalnya pada saat pendataan mungkin penderita sedang relapse lalu mengikuti rehabilitasi dan sembuh menjelang hari $\mathrm{H}$ pemilihan, tapi karena sudah terlanjur didata dalam keadaan tidak fit untuk memilih, ia kehilangan hak pilihnya padahal sudah sembuh dan mampu memilih. Karena itu, KPU wajib mendata semua orang yang telah memenuhi syarat umum sebagai pemilih, tanpa mempertimbangkan penyandang disabilitas mental atau tidak.

Sebagai lanjutan untuk melindungi hak pilih penyandang disabilitas mental, dikeluarkan Pasal 4 Ayat 3 PKPU Nomor 11 Tahun 2018 tentang Penyusunan Daftar Pemilih di dalam negeri dalam Penyelenggaraan Pemilihan Umum yang berusaha mengadopsi putusan Mahkamah Konstitusi berlaku jika ada surat yang mengecualikan bahwa memang seorang penyandang disabilitas mental tidak bisa didata karena gangguan jiwanya bersifat permanen dan/atau akan membutuhkan waktu rehabilitasi yang lebih dari masa pencoblosan untuk sembuh, maka dia boleh untuk tidak didata. Tetapi jika tidak ada surat yang menyatakan bahwa pemilih disabilitas mental itu tidak mampu untuk menjalankan fungsi pemilihan, maka semua harus didata. Apabila ada permintaan untuk diperiksa oleh tenaga medis seperti dokter atau psikiater saat pendataan, maka hal tersebut bertentangan dengan hak penyandang disabilitas.

Pada akhirnya, prinsip keadilan Pemilu (electoral justice) mengatur seluruh ketentuan pelaksanaan Pemilu untuk mewujudkan nilai kejujuran, kebebasan, serta keadilan dalam Pemilu yang menjadi representasi dari cita-cita demokrasi, termasuk di Indonesia. Inklusivitas Pemilu yang dihadirkan dalam konsep keadilan Pemilu memberikan ruang kepada siapapun yang terdiskriminasi untuk mendapatkan kembali haknya melalui aturan yang berlaku (International IDEA, 2010).

Restorasi atau pemulihan hak pilih penyandang disabilitas mental dalam Pemilu ini sesuai dengan unsur keadilan dalam sistem keadilan elektoral, dimana dalam mewujudkan keadilan Pemilu, pertama 
harus dilakukan dengan memberikan hak dan kedudukan yang sama dan setara di mata hukum bagi seluruh warga negara terlepas dari latar belakang dan kondisi diri yang berbeda-beda. Dalam hal ini, dengan memberikan akses terhadap kesempatan yang sama bagi setiap warga negara untuk ikut dalam pemilihan umum, negara telah memenuhi hak politik dasar bagi warganya dan membuka jalan untuk mereka mendapat hak pilihnya yang dijamin negara.

Selanjutnya, untuk menjamin adanya distribusi keadilan dan mewujudkan keadilan yang proporsional, dibutuhkan adanya perlakuan khusus yang dimaksudkan sebagai cara-cara yang akan memfasilitasi kebutuhan-kebutuhan tiap orang yang berbeda-beda. Pada bagian kedua, dibahas mengenai implementasi kebijakan inklusi bagi penyandang disabilitas mental pada Pemilu serentak 2019 di Kota Surabaya, yang tidak hanya didasarkan pada aturan utama yang menjamin hak pilih yang sama bagi setiap warga negara baik yang difabel maupun tidak, tetapi juga melihat dari adanya peraturan-peraturan khusus yang diberlakukan untuk menjamin terpenuhinya kebutuhan-kebutuhan penyandang disabilitas mental dalam melaksanakan Pemilu. Sehingga suara mereka dapat diberikan secara optimal dan berlaku signifikan, sama seperti suara orang lain yang bukan penyandang disabilitas mental.

Hal ini dimulai dengan disebarkannya surat edaran dari KPU Pusat kepada KPU di daerah-daerah yang diteruskan kepada rumah sakit jiwa dan panti rehabilitasi jiwa di Surabaya, serta pemerintahpemerintah daerah di tingkat yang lebih kecil misalnya kecamatan, kelurahan, dan seterusnya yang berisikan kewajiban untuk melakukan pendataan kepada setiap orang yang tidak memiliki gangguan jiwa permanen ke dalam DPT ketika masa pemutakhiran data pemilih atau coklit. Perlakuan khusus yang diberikan pada periode pra-Pemilu ini contohnya dengan menyediakan kolom data disabilitas dan jenisnya yang harus dicatat, sehingga nantinya TPS setempat dapat dipersiapkan agar memudahkan akses bagi semua golongan. Sedangkan untuk Rumah Sakit Jiwa Menur, pendataan dilakukan kepada semua pasien yang sudah tidak dalam fase gaduh-gelisah, tetapi setelah observasi dan screening rutin sampai pada menjelang hari $\mathrm{H}$ pemilihan, yang dinyatakan dapat mengikuti pencoblosan hanya 7 orang dari 200 pasien yang sebelumnya didata. Tahapan screening dan observasi dilakukan masing-masing Dokter Jiwa Penanggung Jawab Pasien (DPJP) dan tim perawat untuk memastikan yang mencoblos pada hari $\mathrm{H}$ benar-benar pasien yang berkapabilitas untuk memilih dengan sadar, tenang, dan rasional.

Pada masa pra-Pemilu ini juga dilakukan sosialisasi tambahan kepada PPS dan KPPS mengenai aturan penyelenggaraan TPS yang melayani pemilih dengan disabilitas mental. Selanjutnya, sosialisasi mengenai hal seputar Pemilu seperti kandidat yang akan berkontestasi dan sebagainya serta tata cara pemilihan juga diberikan kepada para pemilih melalui berbagai medium, misalnya siaran televisi, berita di koran dan majalah atau tabloid, maupun secara langsung menjelang dan ketika hari $\mathrm{H}$ pemilihan. Perbedaan ini terutama terlihat pada rumah sakit jiwa yang melaksanakan Pemilu bagi pasiennya seperti di RSJ Menur Surabaya, dimana isi sosialisasi yang diberikan sama, hanya suasana sosialisasi dan cara penyampaiannya yang disesuaikan dengan kebutuhan dan kondisi pemilih difabel mental. 
Selain itu, di RSJ Menur Surabaya juga dibentuk KPPS yang beranggotakan dokter jiwa dan tenaga medis serta bagian manajemen rumah sakit yang dibantu oleh petugas-petugas dari KPUD Surabaya. Hal ini sebagai langkah pengamanan agar jika terjadi sesuatu yang kurang diinginkan, maka akan dapat ditangani dengan cepat. Selain itu, KPPS dengan tim tersebut lebih mampu menciptakan suasana TPS yang kondusif bagi penyandang disabilitas mental yang ada di sana, karena mereka sudah paham kondisi dan kebutuhan penyandang disabilitas yang terlibat dalam Pemilu.

Pada masa Pemilu, tidak banyak perbedaan yang dilakukan terhadap penyandang disabilitas mental yang memilih di Rumah Sakit Jiwa Menur Surabaya. Desain TPS sama dengan TPS pada umumnya, dengan meja panitia, kursi tunggu, bilik-bilik pemilihan dari kardus, dan kotak surat suara. TPS ditempatkan di ruang utama rumah sakit yang memudahkan akses bagi para pasien dan petugas. Hal berbeda pada hari pemilihan adalah adanya pendamping bagi pasien yang membutuhkan pendampingan pada hari pencoblosan. Para pendamping ini sebelumnya telah terdaftar dalam formulir khusus data pendamping yang sah. Jika pasien tidak membutuhkan pendampingan, pendamping hanya akan membantu menunjukkan tempat bilik pemilihan dan kotak surat suara, tetapi jika membutuhkan pendampingan lebih, maka akan diarahkan mulai dari fungsi masing-masing surat suara sampai cara mencoblos, tanpa melakukan intervensi pilihan pemilih.

Selanjutnya, pasca Pemilu yang lebih berfokus pada evaluasi dari permasalahan dan hambatan selama Pemilu khususnya perihal penerapan Pemilu yang inklusif dan berkeadilan untuk penyandang disabilitas mental di Surabaya. Pertama, hambatan kebijakan. Hambatan kebijakan bukan berarti tidak adanya kebijakan yang pro-disabilitas, tetapi belum meratanya sosialisasi dan implementasinya kepada masyarakat ataupun petugas di lapangan (TPS) tentang perlindungan hak pilih bagi penyandang disabilitas. Kedua, hambatan informasi, seperti kurangnya informasi yang diperoleh penyandang disabilitas mental tentang kandidat dalam Pemilu. Hal ini perlu ditingkatkan dalam bentuk sosialisasi atau model kampanye agar penyandang disabilitas mental dapat mengaksesnya.

Ketiga, adalah hambatan lingkungan. Lingkungan yang dimaksud adalah bagaimana kondisi yang diciptakan oleh penyelenggara agar penyandang disabilitas dapat memiliki suara secara mandiri. Contohnya, bagi pemilih dari kalangan penyandang disabilitas mental, tempatnya harus memiliki akses seperti terjaganya ketenangan di tempat pemungutan suara (TPS), dan petugas tidak memanggil dengan suara yang terlampau keras. Jika diperlukan pendampingan maka dilakukan pendampingan oleh petugas atau pihak keluarga yang terdaftar dalam formulir pendamping hingga ke bilik suara, dan upaya-upaya lain untuk mengantisipasi kambuhnya gangguan jiwa orang tersebut. Hambatan yang keempat, yakni hambatan sikap yang masih banyak terjadi. Artinya, cara petugas KPPS dalam memperlakukan penyandang disabilitas yang datang ke TPS (hal ini terutama dapat terlihat dan dirasakan pada TPS-TPS selain yang ada di RSJ atau panti jiwa) dirasa masih kurang optimal. 


\section{SIMPULAN}

Demi mewujudkan keadilan Pemilu di Indonesia memang membutuhkan proses perbaikan yang terus-menerus. Pihak-pihak yang sudah bergerak untuk melakukan sosialisasi dan mengadvokasi penyandang disabilitas mental tentang Pemilu perlu didukung, terutama oleh pemerintah dan penyelenggara Pemilu. Tidak kalah penting, yang perlu diperhatikan selanjutnya adalah bagaimana informasi yang sudah disampaikan oleh KPU dan organisasi masyarakat penyandang disabilitas ke masyarakat ataupun petugas-petugas di lapangan benar-benar dipahami dan dilaksanakan, seperti cara berinteraksi dengan disabilitas mental, melakukan desain TPS yang memudahkan akses disabilitas mental, dan mendampingi penyandang disabilitas mental dalam memberikan hak pilihnya.

\section{DAFTAR PUSTAKA}

Agustin YN (2016) Penderita Gangguan Jiwa atau Ingatan dapat Menggunakan Hak Pilih. Diakses 28 Desember 2018, dari http://www.mahkamahkonstitusi.go.id/index.php?page=web. Berita\&id=13387\#. WwcwvctEnDc.

Berita Satu (2018) Dialog: Hak Pilih Disabilitas Mental \#1. Diakses 6 Agustus 2019, dari $\mathrm{https} / / / \mathrm{www}$. youtube.com/watch?v=PciT-rnCY30\&t=1s.

Berita Satu (2018) Dialog: Hak Pilih Disabilitas Mental \#2. Diakses 6 Agustus 2019, dari https://www.youtube.com/watch?v=DzXu3GjuVo4\&t=111s.

Berita Satu (2018) Dialog: Hak Pilih Disabilitas Mental \#3. Diakses 6 Agustus 2019, dari https://www.youtube.com/watch?v=UpW7TidD5o0.

Budiarti RM (2019) [Personal Communication] Wawancara 4 Oktober 2019.

Dewan Perwakilan Rakyat (n.d.) Undang-Undang Republik Indonesia Nomor 8 Tahun 2015 Tentang Perubahan Atas Undang-Undang Nomor 1 Tahun 2015 Tentang Penetapan Peraturan Pemerintah Pengganti Undang-Undang Nomor 1 Tahun 2014 Tentang Pemilihan Gubernur, Bupati, Dan Walikota Menjadi Undang-Undang. Diakses 16 Februari 2019, dari http://www.dpr.go.id/dokjdih/document/uu/1627.pdf.

Dewan Perwakilan Rakyat (n.d.) Undang-Undang Republik Indonesia Nomor 8 Tahun 2012 Tentang Pemilihan Umum Anggota Dewan Perwakilan Rakyat, Dewan Perwakilan Daerah, Dan Dewan Perwakilan Rakyat Daerah. Diakses 16 Februari 2019, dari http://www.dpr.go.id/dokjdih/document/uu/268.pdf.

Fachrudin F (2016) MK Terima Sebagian Uji Materi Terkait Hak Pilih Pengidap Gangguan Jiwa. Diakses $\quad 5 \quad$ Agustus 2019, dari https://nasional.kompas.com/read/2016/10/13/15462631/mk.terima.sebagian.uji.materi.terkait. hak.pilih.pengidap.gangguan.jiwa?page=all.

Farisa FC (2018) Hak Pilih Penyandang Disabilitas Mental Disebut Lahir dari Perjuangan Panjang. Diakses 17 Februari 2019, dari https://nasional.kompas.com/read/2018/11/24/22573761/hakpilih-penyandang-disabilitas-mental-disebut-lahir-dari-perjuangan.

Hasanah S (2018) Arti Landasan Filosofis, Sosiologis, dan Yuridis. Diakses 5 Agustus 2019, dari https://www.hukumonline.com/klinik/detail/tt59394de7562ff/arti-landasan-filosofis-sosiologis--dan-yuridis

Hukum Online (n.d.) Undang-Undang nomor 7 tahun 2017. Diakses 5 Agustus 2019, dari https://m.hukumonline.com/pusatdata/detail/lt59ba5511ab93b/undang-undang-nomor-7-tahun2017

International IDEA (2010) Electoral Justice: An Overview of the International IDEA Handbook. Terjemahan oleh DuaBahasa. Jakarta: Indonesia Printer. 
Kamilah E (2014) Bawaslu: Coret hak pilih orang dengan gangguan jiwa, pelanggaran HAM. Diakses 28 April 2018, dari http://kbr.id/03-2014/bawaslu_coret_hak_pilih_orang_dengan_ gangguan_jiwa_pelanggaran_ham/3445.html.

Kementerian Hukum dan HAM (n.d.) Undang-Undang Republik Indonesia Nomor 19 Tahun 2011 Tentang Pengesahan Convention On The Rights Of Persons With Disabilities (Konvensi Mengenai Hak-Hak Penyandang Disabilitas). Diakses 16 Februari 2019, dari http://ditjenpp.kemenkumham.go.id/arsip/ln/2011/uu19-2011bt.pdf

Komnas HAM (n.d.) Deklarasi Universal Hak Asasi Manusia. Diakses 16 Februari 2019, dari https://www.komnasham.go.id/files/1475231326-deklarasi-universal-hak-asasi--\$R48R63.pdf

Komnas HAM (n.d.) Undang-Undang Republik Indonesia Nomor 39 Tahun 1999 Tentang Hak Asasi Manusia Diakses 16 Februari 2019, dari https://www.komnasham.go.id/files/1475231474-uunomor-39-tahun-1999-tentang-\$H9FVDS.pdf

Kompas TV (2019) Dialog: Hak Pilih bagi Penyandang Disabilitas (Bag. 1). Diakses 6 Agustus 2019, dari https://www.youtube.com/watch?v=0jZ3VKF0X44.

Kompas tv (2019). Dialog: Hak Pilih bagi Penyandang Disabilitas (Bag. 2). Diakses 6 Agustus 2019, dari https://www.youtube.com/watch?v=APOCBfu40hA.

KPUD Surabaya (2019) [Personal Communication] Wawancara 10 Oktober 2019.

Mashabi S (2018) Bukan Orang Gila, tapi Disabilitas Mental yang Didata KPU untuk Jadi Pemilih. Diakses 17 Februari 2019, dari https://www.merdeka.com/politik/bukan-orang-gila-tapidisabilitas-mental-yang-didata-kpu-untuk-jadi-pemilih.html.

Safutra I (2018) KPU Siapkan Form Khusus untuk Pendamping Pemilih ODGJ. Diakses 5 Agustus 2019, dari https://www.jawapos.com/nasional/pemilihan/26/11/2018/kpu-siapkan-form-khususuntuk-pendamping-pemilih-odgj/.

Scheid TL \& Tony NB (2009) A Handbook for The Study of Mental Health: Social Contexts, Theories, and Systems (Second Edition). New York: Cambridge University Press.

Talk Show tvOne (2018) Gangguan Jiwa Layak Nyoblos? - Apa Kabar Indonesia Pagi. Diakses 6 Agustus 2019, dari https://www.youtube.com/watch?v=lWSpi22KHwY\&t=1204s.

Yuridis Indonesia (n.d.) Salinan Putusan MK nomor 135/PUU-XIII/2015 tentang Hak Pilih bagi Pengidam Gangguan Jiwa non-Permanen. Diakses 5 Agustus 2019, dari https://yuridis.id/wpcontent/uploads/2018/04/Hak-Pilih-Bagi-Pengidap-gangguan-jiwa-non-permanen.pdf 